\title{
PENGARUH LINGKUNGAN KERJA DAN WORK FORM HOME TERHADAP KINERJA PEGAWAI BADAN PEMERIKSA KEUANGAN PROVINSI SUMATERA SELATAN DI MASA PANDEMI COVID-19
}

\author{
Yusro Hakimah $^{1)}$, Baidowi Abdie ${ }^{2)}$, Umi Hasanah ${ }^{3)}$ \\ 1,2,3)Dosen jurusan manajemen, Universitas Tridinanti Sumatera Selatan, Indonesia
}

\begin{tabular}{|c|c|}
\hline INFORMASI ARTIKEL & $A B S T R A K$ \\
\hline $\begin{array}{l}\text { Submitted: } \\
01 / 12 / 2021 \\
\text { Revised: } \\
\text { 15/12/2021 } \\
\text { Accepted: } \\
\text { 25/12/2021 } \\
\text { Online-Published: } \\
\text { 31/12/2021 }\end{array}$ & $\begin{array}{l}\text { Penelitian ini membahas mengenai kinerja Pegawai Badan Pemeriksa } \\
\text { Keuangan (BPK) Perwakilan Provinsi Sumatera Selatan selama pandemi } \\
\text { Covid-19. Tujuan penelitian ini dilakukan untuk mengetahui Pengaruh } \\
\text { Lingkungan kerja dan work form home terhadap Kinerja Pegawai. Data } \\
\text { diperoleh melalui penyebaran kuesioner dengan google form kepada } 54 \\
\text { pegawai menggunakan teknik Sampling Jenuh. Dalam Pengolahan data } \\
\text { digunakan software SPSS. Metode yang dipakai adalah analisis berbentuk } \\
\text { kualitatif yang dikuantitatifkan dan dianalisis menggunakan analisis regresi } \\
\text { berganda. Hasil penelitian yang dilakukan secara simultan antara semua } \\
\text { variabel yang diteliti menggambarkan bahwa terdapat pengaruh lingkungan } \\
\text { kerja dan work form home positif yang signifikan terhadap kinerja karyawan. } \\
\text { Hasil penelitian membuktikan bahwa lingkungan kerja berpengaruh positif } \\
\text { signifikan terhadap kerja, work from home memberikan pengaruh positif yang } \\
\text { signifikan terhadap kinerja karyawan pada masa Covid-19. } \\
\text { Kata Kunci: Lingkungan kerja, WFH, Kinerja. }\end{array}$ \\
\hline
\end{tabular}

\begin{abstract}
This study discusses the performance of employees of the Supreme Audit Agency (BPK) Representative of the Province of South Sumatra during the Covid-19 pandemic. The purpose of this study was to determine the effect of the work environment and work form home on employee performance. The data was obtained by distributing questionnaires using google form to 54 employees using the Saturated Sampling technique. In data processing used SPSS software. The method used is qualitative analysis which is quantified and analyzed using multiple regression analysis. The results of research conducted simultaneously between all the variables studied illustrate that there is a significant positive influence of the work environment and work form home on employee performance. The results of the study prove that the work environment has a significant positive effect on work, work from home has a significant positive effect on employee performance during the Covid-19 period.

Keywords: Work environment, WFH, Performance.
\end{abstract}

\section{A. PENDAHULUAN}

Maret 2020, rakyat Indonesia dikejutkan dengan wabah virus corona (Covid-19) yang di umumkan secara resmi oleh pemerintah. Berawal dari Wuhan sebuah kota yang terletak di Provinsi Hubei, China di mana pertama kali penduduknya diketahui terjangkit virus Covid-19 pada November 2019 telah menginfeksi lebih dari 126.000 orang di 123 negara mulai dari Asia, Eropa, AS, hingga Afrika Selatan (Kompas, 2020).
Imbas dari adanya pandemi ini terjadi pada lintas sektor seperti perekonomian, bisnis, pendidikan, sosial, lingkungan bahkan aktivitas dalam bekerja. Selain itu pandemi juga berdampak pada sektor pekerjaan. Saat ini 660 juta pegawai dari 20 negara perwakilan, 38 juta pegawai diantaranya atau sekitar $5,7 \%$ dari total pegawai telah mengajukan asuransi pengangguran selama pandemi. (Rothwell, 2020). 
Indonesia sendiri, sebagai negara dengan kasus tertinggi nomor 3 di Asia dengan jumlah kasus terkonfirmasi positif mencapai angka 248 ribu, lebih dari 3,9\% atau sekitar 9 ribu jiwa terkonfirmasi meninggal dunia (Satgas Covid-19, 2020). Provinsi Sumatera Selatan menjadi salah satu daerah yang menyumbang kasus positif corona terbanyak. Hingga pertengahan tahun 2021, Provinsi Sumatera Selatan masuk dalam 10 besar daerah yang terinfeksi Covid di Indonesia. Menurut data dari Satgas Penanganan Covid19, kasus Covid-19 di Sumsel terus melonjak, sehingga pemerintah Provinsi Sumatera Selatan melakukan kebijakan WFH bagi PNS dimulai bulan Maret 2020, setelah adanya penetapan darurat kesehatan masyarakat oleh Pemerintah yang diakibatkan oleh Pandemi Covid-19. melalui Surat Edaran (SE) Menteri PANRB No 19 Tahun 2020 tanggal 16 Maret 2020 tentang Penyesuaian Sistem Kerja PNS dalam Upaya Pencegahan Penyebaran Covid-19 di Lingkungan Instansi Pemerintah. Masa pelaksanaan WFH bagi PNS sesuai SE Menpan RB No 19 Tahun 2020 berakhir pada 31 Maret 2020, kemudian dilakukan perubahan SE beberapa kali hingga pada tanggal 29 Mei 2020, dikeluarkan SE Menpan RB No 58 Tahun 2020 tentang Sistem Kerja Pegawai PNS dalam Tatanan Normal Baru

Badan Pemeriksa Keuangan (BPK) merupakan lembaga pemeriksa pengelolaan dan pertanggung jawaban keuangan negara. BPK memiliki perwakilan di setiap provinsi, salah satunya adalah BPK Perwakilan Provinsi Sumatera Selatan yang bertugas memeriksa pengelolaan dan tanggung jawab keuangan negara dengan lingkup pemeriksaan atas Pemerintah Daerah yang berada di wilayah provinsi Sumatera Selatan.

Kinerja Pegawai yang belum optimal merupakan kendala yang sering terjadi hampir di setiap lembaga/organisasi. Hal yang sama juga terjadi di BPK Perwakilan
Provinsi Sumatera Selatan. Sistem kerja selama masa pandemi diberlakukan bekerja jarak jauh dan diberlakukan kerja secara shiftting (sistem jadwal/bergantian). Cara kerja yang dilakukan tersebut menyebabkan aspek penyelenggaranaan pelayanan publik berubah membuat masyarakat kebanyakan mengeluh karena pelayanan kepada masyarakat berjalan sangat lambat dan sebagian pegawai menganggap WFH sebagai libur/cuti dirumah.

Kesadaran pegawai terhadap peraturan lembaga/organisasi dirasakan masih sangat rendah khususnya di wilayah kerja BPK Perwakilan Provinsi Sumatera Selatan. Hal ini dibuktikan dengan tingkat absensi pegawai yang masih datang terlambat dan pulang lebih awal dengan berbagai alasan. Pemeriksa Keuangan Perwakilan Provinsi Sumatera Selatan memiliki berbagai macam cara dan program kerja untuk meningkatkan kinerja BPK Perwakilan Provinsi Sumatera Selatan akan tetapi, tidak semua pegawai mampu melaksanakan dan menyelesaikan berbagai program kerja BPK Perwakilan Provinsi Sumatera Selatan dengan baik dan tepat waktu. Pegawai cenderung berpikiran santai dan tidak peduli dengan target yang harus dicapai sehingga pegawai dinilai memiliki motivasi kerja yang rendah dan kurang bersemangat dalam meningkatkan kinerjanya. Sebagian pegawai terjebak dalam zona nyaman dengan melaksanakan tugastugas rutin dan memperoleh gaji dan penghasilan rutin setiap bulannya dan bagi pegawai yang dimutasi juga seringkali mengalami demotivasi kerja. Kondisi ini tentu saja berdampak pada stagnansi dan penurunan kinerja BPK Perwakilan Provinsi Sumatera Selatan.

Kinerja Pegawai dinilai masih kurang optimal tercermin dengan tidak tercapainya target kinerja lembaga ditambah lagi masa pandemi covid-19 yang menjadi alasan tersendiri bagi pegawai untuk tidak dapat bekerja secara optimal. Produktivitas yang 
dicapai cenderung menurun. Kondisi ini tentu saja sangat mengkhawatirkan dan memerlukan perhatian dan kebijakan pimpinan untuk melakukan evaluasi dan segera melakukan pembenahan terhadap kondisi tersebut. Laporan Kinerja pada tahun - tahun belakang menunjukkan bahwa BPK Perwakilan Provinsi Sumatera Selatan mengalami penurunan. Hal ini menggambarkan bahwa kinerja yang dicapai belum optimal dan masih banyak pekerjaan rumah yang harus dibenahi oleh BPK Perwakilan Provinsi Sumatera Selatan guna meningkatkan kinerjanya di masa datang.

Lingkungan kerja selama pandemi sebagai keadaan ideal dalam mendukung pelaksanaan tugas sesuai aturan dalam rangka mendukung optimalisasi kerja. Salah satu syarat agar semangat kerja dapat ditumbuhkan dalam lingkungan kerja ialah adanya pembagian kerja yang tuntas sampai kepada pegawai atau petugas yang paling bawah, sehingga setiap orang tahu dengan sadar apa tugasnya, bagaimana melakukannya, kapan pekerjaan dimulai dan selesai, seperti apa hasil kerja yang disyaratkan, dan kepada siapa mempertanggung jawabkan hasil pekerjaan. Lingkungan kerja sebaiknya ditanamkan dalam diri setiap pegawai, bukan paksaan tetapi didasarkan atas kesadaran dari dalam diri setiap pegawai untuk disiplin pikiran Lingkungan kerja harus ditumbuh kembangkan agar tumbuh pula ketertiban dan efisiensi. Lingkungan kerja adalah keseluruhan lingkungan dimana seseorang bekerja, meliputi metode kerja dan pengaturan kerjanya (Sedarmayanti, 2017). Lingkungan kerja juga merupakan salah satu hal yang mempengaruhi pelaksanaan tugas karyawan secara optimal sehingga perlu diperhatikan oleh perusahaan, yang meliputi suasana kerja, hubungan rekan kerja, dan tersedianya fasilitas kerja (Arianto \& Kurniawan, 2020).

\section{Kajian Pustaka}

\section{Kinerja}

Menurut (Mangkunegara, 2003) kinerja adalah pelaksanaan tanggung jawab karyawan dengan pencapaian hasil kerja sesuai dengan kualitas dan kuantitas yang ada didalam perusahaan.

Menurut (Kasmir, 2016) indikator kinerja yaitu Kualitas (Mutu), Kuantitas (Jumlah), Waktu (Jangka waktu) Penekanan Biaya Pengawasan dan Hubungan antar Karyawan.

\section{Lingkungan kerja}

Menurut (Sedarmayanti, 2017) lingkungan kerja adalah keseluruhan alat perkakas dan bahan yang dihadapi, lingkungan sekitarnya di mana seseorang bekerja, metode kerjanya, serta pengaturan kerjanya baik sebagai perseorangan maupun sebagai kelompok

Menurut (Sedarmayanti, 2017) beberapa indikator dari lingkungan kerja yaitu: Penerangan, Suhu udara, Sirkulasi udara, ukuran ruang kerja, Tata letak ruang kerja, Privasi ruang kerja Kebersihan, Kebersihan, Suara bising, Penggunaan warna, dan Peralatan Kerja

Indikator pada penelitian ini berkaitan dengan fenomena yang terjadi adalah sirkulasi udara, ukuran ruang kerja, dan peralatan kerja.

Lingkungan kerja dibedakan menjadi 2 macam, yaitu lingkungan kerja fisik dan lingkungan kerja non fisik.

1. Lingkungan kerja fisik adalah semua kondisi fisik yang terdapat di sekitar tempat kerja dan berpengaruh baik secara langsung maupun secara tidak langsung bagi karyawan (Sedarmayanti, 2009). Lingkungan fisik dibagi menjadi 2 kategori yaitu:

a. Lingkungan yang langsung berhubungan dengan karyawan Seperti: 
pusat kerja, kursi, meja dan sebagainya.

b. Lingkungan perantara yang mempengaruhi kondisi manusia, misal: temperatur, kelembaban, sirkulasi udara, pencahayaan, kebisingan, getaran mekanis, bau tidak sedap, warna, dan lain-lain

2. Lingkungan non fisik adalah semua kondisi psikis di lingkungan kerja yang mempengaruhi karyawan untuk melaksanakan kegiatannya secara optimal, sehat, aman, dan nyaman (Sedarmayanti, 2009). Lingkungan kerja non fisik dapat diukur dengan indikator sebagai berikut (Analisa, 2011):

a. Hubungan dengan rekan kerja.

Hubungan harmonis dengan rekan kerja tentunya akan memberikan kondisi psikis yang positif bagi karyawan.

b. Standar Kerja.

Meliputi persyaratan tugas, fungsi atau perilaku yang ditetapkan oleh pemberi kerja sebagai sasaran yang harus dicapai oleh karyawan. Semakin berat standar yang ditetapkan, kondisi psikis karyawan akan semakin buruk.

c. Prosedur Kerja adalah rangkaian peraturan kerja yang dalam menyelesaikan suatu pekerjaan. Tingkat kesulitan prosedur akan mempengaruhi kondisi psikis karyawan.

d. Kejelasan Tugas yaitu sejauh mana pekerjaan itu menuntut penyelesaian secara utuh dan dapat dikenali karyawan. Semakin baik kejelasan tugas, semakin baik pula kondisi psikis karyawan.

e. Sistem Penghargaan (reward system) adalah sebuah program yang digunakan untuk menghargai pencapaian sasaran atau proyek oleh karyawan. Adanya sistem penghargaan yang tidak adil akan memperburuk kondisi psikis karyawan.

\section{Work from Home}

Mungkasa (2020) menyatakan bahwa diperlukan sebuah penyesuaian yang harus dilakukan oleh pegawai dalam menerapkan WFH.

Menurut Gądecki et al.,(2018) yaitu:

1. Ruangan: transformasi ruang pribadi rumah (sebagai tempat realisasi kesukaan dan mengekspresikan diri) ke dalam ruang publik semu;

2. Waktu: penggunaan ruang pribadi oleh ruang kerja yang mengarah kepada tabrakan dua yang berbeda sistem waktu: waktu siklik (pekerjaan rumahtangga) dan waktu linier (tugas profesional), yang tumpang tindih;

3. Peran Sosial: narasi tentang diri sendiri sebagai pekerja dari rumah, sebuah emanasi peran dan posisi teleworker yang konstan dilakukan.

work from home merupakan usaha perusahaan dalam menjamin keamanan kesehatan karyawan dari wabah pandemi Covid-19 dan patuh terhadap peraturan pemerintah terkait kebijakan bekerja dari rumah (Rakha,2021). Work from home memiliki tiga tahapan, yaitu: proses perencanaan, proses lapangan, dan pengevaluasian hasil kerja. Penerapan work from home memiliki lima konsep perencanaan, yaitu: hubungan keluarga, sikap profesionalitas, keseimbangan kerja, penggunaan aplikasi media online, dan patuh pada aturan pemerintah.

\section{B. METODE PENELITIAN}

Data yang digunakan dalam penelitian ini adalah data primer dan sekunder. Data primer berupa hasil dari kuesioner yang disebar kepada para responden menggunakan google form kepada 54 pegawai menggunakan teknik Sampling Jenuh. sedangkan data sekunder berupa informasi, literature dan wawancara. Pengolahan data pada penelitian ini menggunakan software SPSS. Metode yang digunakan adalah analisis berbentuk kualitatif yang dikuantitatifkan.

Uji instrumen yang dilakukan dalam penelitian ini adalah uji validitas dan uji reliabilitas dan metode analisis yang 
digunakan dalam penelitian ini adalah metode analisis regresi linier berganda, uji $\mathrm{F}$, uji $\mathrm{t}$ dan koefisien determinasi R2 . Analisis ini digunakan untuk menilai pengaruh lingkungan kerja dan Work from Home terhadap kinerja pegawai.

Persamaan Regresi Linear Berganda:

$\mathrm{Y}=\mathrm{a}+\mathrm{b}_{1} \mathrm{X}_{1}+\mathrm{b}_{2} \mathrm{X}_{2}+\mathrm{e}$

Dimana :

$\mathrm{Y}=$ Kinerja Karyawan

$\mathrm{a}=$ Konstanta

$\mathrm{b}_{1}=$ Koef. Regresi L ingkungan Kerja

$\mathrm{X}_{1}=$ Lingkungan Kerja

$\mathrm{b}_{2}=$ Koef. Regresi Variabel WfH

$\mathrm{X}_{2}=$ Work from Home

\section{HASIL DAN PEMBAHASAN}

Tabel 1. Hasil Uji Simultan (Uji F)

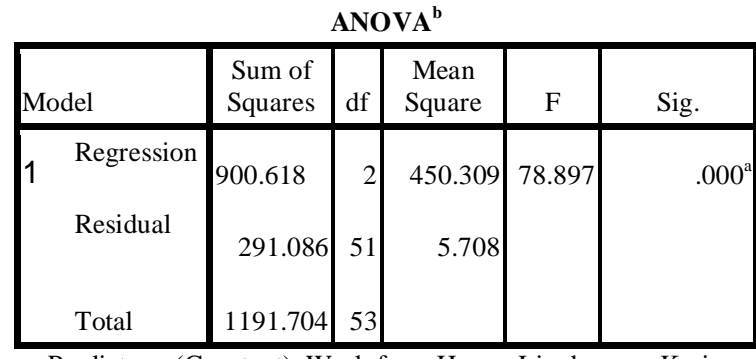

a. Predictors: (Constant), Work from Home, Lingkungan Kerja

b. Dependent Variable: Kinerja

Dari hasil analisis regresi linier berganda, diketahui adanya pengaruh yang positif dari lingkungan kerja dan work from home terhadap kinerja pegawai BPK Perwakilan Provinsi Sumatera Selatan selama masa pandemi covid-19. Hasil uji hipotesis secara simultan menunjukkan bahwa ada pengaruh yang signifikan lingkungan kerja dan work from home terhadap kinerja pegawai BPK Perwakilan Provinsi Sumatera Selatan sebesar 79\%. Sedangkan sisanya sebesar $21 \%$ dijelaskan oleh variabel-variabel lain yang tidak termasuk dalam penelitian ini.
Tabel 2. Hasil uji regresi linier berganda

Coefficients $^{\mathrm{a}}$

\begin{tabular}{|c|c|c|c|c|c|c|}
\hline \multirow{2}{*}{\multicolumn{2}{|c|}{ Model }} & \multicolumn{2}{|c|}{$\begin{array}{l}\text { Unstandardized } \\
\text { Coefficients }\end{array}$} & \multirow{2}{*}{$\begin{array}{c}\begin{array}{c}\text { Standardized } \\
\text { Coefficients }\end{array} \\
\text { Beta }\end{array}$} & \multirow[b]{2}{*}{$t$} & \multirow[b]{2}{*}{ Sig. } \\
\hline & & B & $\begin{array}{l}\text { Std. } \\
\text { Error }\end{array}$ & & & \\
\hline \multirow[t]{3}{*}{1} & (Constant) & 11.137 & 2.822 & & 3.947 & .000 \\
\hline & $\begin{array}{l}\text { Lingkungan } \\
\text { Kerja }\end{array}$ & .637 & .069 & .723 & 9.232 & .000 \\
\hline & $\begin{array}{l}\text { Work from } \\
\text { Home }\end{array}$ & .271 & .085 & .251 & 3.201 & .002 \\
\hline
\end{tabular}

Berdasarkan tabel 2 dapat dibuat pers. regresi linier berganda sebagai berikut :

$$
Y=11,137+0,637 X 1+0,271 X 2+e
$$

Dimana :

$\mathrm{Y}=$ Kinerja pegawai BPK

$\mathrm{X} 1$ = Lingkungan Kerja

$\mathrm{X} 2=$ Work From Home

$\mathrm{E}=$ Standar error

Berdasarkan tabel 2 dapat diketahui seberapa besar pengaruh masing-masing variabel independen secara parsial (individual) terhadap variabel dependen adalah sebagai berikut :

1. Pengaruh variabel lingkungan kerja terhadap kinerja pegawai BPK Perwakilan Provinsi Sumatera Selatan.

Pada tabel 2 variabel lingkungan kerja memiliki nilai signifikansi $0,000<0,05$ sehingga dapat disimpulkan bahwa Ho ditolak dan Ha diterima, artinya variabel lingkungan kerja berpengaruh signifikan positif terhadap kinerja PNS Kota Palembang.

2. Pengaruh work from home terhadap Kinerja pegawai BPK Perwakilan Provinsi Sumatera Selatan.

Pada tabel 2 dimana variabel work from home memiliki nilai signifikansi $0,002<0,05$ dapat disimpulkan bahwa Ho ditolak dan $\mathrm{Ha}$ diterima, artinya work from home berpengaruh signifikan positif 
terhadap kinerja pegawai BPK Perwakilan Provinsi Sumatera Selatan.

\section{Pengaruh Lingkungan Kerja terhadap Kinerja pegawai BPK Perwakilan Provinsi Sumatera Selatan.}

Pandemi covid 19 mendorong adanya kebijakan baru pada lingkungan kerja yakni hubungan rekan kerja lebih dibatasi dengan keharusan menjaga jarak, menggunakan masker dan mencuci tangan dengan sabun atau pembersih tangan (handsanitizer) selama aktivitas bekerja terkait pelaksanaan protokol kesehatan covid- 19. Perubahanperubahan yang terjadi dilingkungan kerja membuat pegawai sedikit perasaan terbebani dan rasa takut akan terpapar covid-19 membuat pegawai lebih hati-hati dalam bekerja (tidak banyak ngobrol dengan rekan), lebih perhatian pada kesehatan diri sendiri maupun orang lain, terciptanya kebiasaan baru untuk hidup lebih sehat dan bersih. Hasil ini semakin memperkuat penelitian (Sutrisno, 2020) yang menyatakan bahwa lingkungan kerja berdampak pada kondisi karyawan.

\section{Pengaruh work from home terhadap Kinerja pegawai BPK Perwakilan Provinsi Sumatera Selatan}

WFH bagi pegawai BPK Perwakilan

Provinsi Sumatera Selatan merupakan sebagai kegiatan melaksanakan tugas kedinasan, menyelesaikan output, koordinasi, rapat/pertemuan, dan tugas lainnya dari tempat tinggal pegawai. Bekerja dari rumah banyak yang harus dipersiapkan seperti, ruang kerja pribadi, kenyamanan, keterampilan, waktu kerja dan pelayanan, dapat membedakan dan memisahkan antara pekerjaan rumah dengan pekerjaan kantor serta aspirasi.

Dari sisi pegawai, Healthfield (2019) dalam Mungkasa (2020) menjelaskan bahwa Pegawai yang melakukan pekerjaan dengan sistem jarak jauh dapat menghindari kemacetan sehingga dapat mengurangi waktu perjalanan dan mengurangi tingkat stres. Selain itu, menghemat waktu dan mengurangi biaya perjalanan.
Bagi organisasi, mengizinkan pegawainya bekerja dari rumah juga memberikan keuntungan dalam jangka pendek dan jangka panjang. Organisasi dapat menghemat biaya operasional, karena tidak perlu membayar uang transport, uang makan, biaya listrik, dan AC dan biaya operasional yang lain (Hendytio, 2020).

Kurangnya peralatan atau kelengkapan sarana dan prasarana di rumah dalam menunjang pekerjaan akan menghambat kinerja mereka untuk melayani publik secara baik.

Tingkat kondusifitas bekerja di rumah juga menjadi unsur penentu efektifitas kerja pegawai. Rumah atau Kos yang sejatinya digunakan untuk tempat istirahat. Bekerja dari rumah bagi orang yang tepat akan dapat meningkatkan produktivitas. Pegawai dengan bidang tertentu seperti teknologi informasi, penelitian dan pengembangan, dan profesi lain yang memerlukan detail dan waktu panjang untuk berkonsentrasi akan cenderung cocok bekerja dari rumah, karena mereka dapat memanfaatkan waktu yang seharusnya digunakan untuk perjalanan ke kantor menjadi waktu kerja yang produktif, selain menghindari gangguan-gangguan lain yang muncul jika bekerja di kantor.

Bekerja dari rumah secara efektif tidak berlaku bagi semua pekerja atau semua jenis pekerjaan (Hendytio, 2020). Pemerintah baik pusat atau daerah harus lebih bersinergi dan berkonsolidasi dalam pengambilan kebijakan terutama yang berkaitan dengan urusan metode kerja Work From Home pegawai. Karena tidak dipungkiri peran pegawai dalam rangka membantu menuntaskan pandemi Covid-19 sangat vital, maka kebijakan-kebijakan yang diambil harus pro dan mendukung kinerja para pegawai dirumah

\section{SIMPULAN DAN SARAN Simpulan}

Hasil uji hipotesa dari penelitian ini adalah sebagai berikut:

1. Lingkungan kerja berpengaruh positif dan signifikan terhadap kinerja Pegawai BPK Perwakilan Provinsi Sumatera Selatan; 
2. Work form home berpengaruh positif dan signifikan terhadap Kinerja Pegawai BPK Perwakilan Provinsi Sumatera Selatan;

3. Lingkungan kerja dan Work form home berpengaruh signifikan signifikan terhadap kinerja Pegawai BPK Perwakilan Provinsi Sumatera Selatan;

\section{Saran}

Berdasarkan kesimpulan yang dihasilkan pada penelitian ini, maka penulis memberikan saran kepada beberapa pihak sebagai berikut: Perlu adanya keseimbangan mengenai pengaturan jadwal WFH dan WFO untuk menghindari adanya kecemburuan atau perasaan diperlakukan tidak adil dari pegawai. Dari sisi instansi, perlu adanya dukungan infrastruktur dan kebijakan yang mengatur secara jelas dan tegas perihal penjadwalan kehadiran pegawai, kedisiplinan bekerja, pelaporan kinerja, kompensasi bahkan sanksi yang diterima pegawai dalam pelaksanaan WFH. Untuk aktivitas kantor dilakukan pembinaan kepada tenaga kebersihan kantor terkait pencegahan penyebaran Covid-19. Kebijakan lain dalam pencegahan dan pengendalian Covid-19 di lingkungan kerja BPK Perwakilan Provinsi Sumatera Selatan adalah membentuk Tim pencegahan Covid-19 yang ditetapkan dengan Keputusan Pimpinan Perangkat Daerah.

\section{E. DAFTAR RUJUKAN}

Arianto, N., \& Kurniawan, H. (2020). Pengaruh Motivasi dan Lingkungan Kerja Terhadap Kinerja Karyawan. JENIUS (Jurnal Ilmiah Manajemen Sumber Daya Manusia), 3(3), 312. https://doi.org/10.32493/jjsdm.v3i3.4869

KemenpanRB. (2020). SE MenpanRB No 58 Tahun 2020 tentang Sistem Kerja Pegawai ASN dalam Tatanan Normal Baru.

Hendytio, M. K. (2020). Bekerja dari Rumah: Menanam Kultur Kerja Fleksibel. CSIS Commentaries DMRU-020, (March).
Mungkasa, O. (2020). Bekerja dari Rumah ( Working From Home / WFH ): Menuju Tatanan Baru Era Pandemi COVID 19 Bekerja dari Rumah ( Working From Home / WFH ): Menuju Tatanan Baru Era Pandemi COVID 19. The Indonesian Journal of Development Planning, IV(2), 126-150.

Sedarmayanti. (2017). Sumber Daya Manusia dan Produktivitas Kerja. Bandung: CV Mandar Maju.

Sutrisno, S. (2020). Analysis Of Compensation And Work Environment on Turnover Intention With Employee Satisfaction As Intervening Variable in PT . Hartono Istana Technology at Semarang. Serat Acitya - Jurnal Ilmiah UNTAG Semarang, 1(1), 13-29. 